\title{
6 On the Place-Name Isle of Dogs
}

Laura Wright

University of Cambridge

\section{Introduction}

In a contribution to the study of the Ormulum (Johannesson 2012), Professor Nils-Lennart Johannesson pinpointed, by means of pictorial as well as written evidence, the social nuance inherent in Orm's metaphor of hunting with nets and dogs to represent the disciples' catching of men's souls for their Lord. Professor Johannesson showed how trapping deer in nets for use as food was the workaday task of servants, as opposed to the lordly pursuit of hunting as a pastime by giving chase. Orm's net metaphor (spelless nett 'net of preaching'), therefore, aligned his rendition of the Gospels with the servant class: the disciples serve their master. Professor Johannesson notes that Orm's hunting dogs were not present in his Latin source texts but were his own invention, and presumably reflect twelfth-century Lincolnshire reality, where his audience would have expected dogs to accompany hunting (Johannesson 2OI 2: 237-238). In what follows I continue with the theme of dogs, the dogs in question being not literal but to do with word-play.

\section{Explanations for the place-name Isle of Dogs}

The place-name Isle of Dogs refers in Present-Day English to the land within a meander of the River Thames in East London. In high Victorian style, B.H. Cowper tells us that the Isle of Dogs is "embosomed, by our noble river, which describes a magnificent curve in the form of a horseshoe from Limehouse to Blackwall" (Cowper I 853: I). The land embosomed by this magnificent curve was not, historically, an island. It was artificially made into an island when the West India Docks were

How to cite this book chapter:

Wright, L. 20I 5 . On the Place-Name Isle of Dogs. In: Shaw, P., Erman, B., Melchers, G. and Sundkvist, P. (eds) From Clerks to Corpora: essays on the English language yesterday and today. Pp. 87-I I 6. Stockholm: Stockholm University Press. DOI: http://dx.doi. org/ıo.16993/bab.f License: CC-BY. 
created in 1802 , by means of the narrow channels of the West India Dock Canal at Limehouse and Blackwall, but this was almost three hundred years after the place-name Isle of Dogs came into use. Strype (I720), Cunningham (I 849: vol 2, 4I7) and Mills (2004: I 2I) list the following explanations for the name Isle of Dogs:

I.

Next is the Isle of Dogs; being a low Marshy Ground, so called, as is reported, for that a Waterman carried a Man into this Marsh, and there murthered him. The Man having a Dog with him, he would not leave his Master; but Hunger forced him many times to swim over the Thames to Greenwich; which the Waterman who plied at the Bridge observing, followed the Dog over; and by that means the murthered Man was discovered. Soon after the Dog swimming over to Greenwich Bridge, where there was a Waterman seated, at him the Dog snarled, and would not be beat off, which the other Watermen perceiving, (and knowing of the Murther) apprehended this strange Waterman; who confessed the Fact, and was condemned and executed.

(Strype (ed.) I720: Vol I, Book I, 43)

My objection to this explanation is that there is no supporting evidence, and the date of $\mathrm{I} 720$ is two hundred years after the date of the first attestation of the name Isle of Dogs. Plus, only one dog is mentioned. ${ }^{\mathrm{I}}$

2.

The fertile Soil of the Marsh here is much admired, usually known by the Name of The Isle of Dogs: So called, because, when our former Princes made Greenwich their Country Seat, and used it for Hunting, (they say), the Kennels for their Dogs were kept on this Marsh; which usually making a great Noise, the Seamen and others thereupon called the Place The Isle of Dogs: Though it is not an Isle, indeed, scarce a Peninsula, the Neck being about a Mile in length.”

(Strype (ed.) I720: Vol 2, Book 6, IO2)

This explanation was given to John Strype by the Reverend

${ }^{1}$ My grateful thanks to Prof Richard Coates, who asked me about the Isle of Dogs in the first place - and who noticed the singularity of dogs in the first explanation, which I had overlooked. I am also grateful to Prof Ian Donaldson, Peter Guillery, Prof Derek Keene and Prof Nicholas Rodger for criticising and commenting on earlier drafts, and to Steve Roberts for supplying the fruiterers' number-system discussed in Section 5 . 
Dr Josiah Woodward, Minister of the Chapel and Hospital of Poplar. Again, there is no evidence, and the dating is two hundred years after the first attested usage.

3. That Isle of Dogs was originally Isle of Ducks, or possibly Isle of Docks.

My objection here is that there are no written occasions on which the area is referred to as either of these, so far as I know. Voiced word-final stops do not usually become devoiced in London English, and there is no obvious motivation for the replacement of a semantically-transparent and contextuallyrelevant word (whether ducks or docks) with a less relevant one.

4. That Isle of Dogs was originally Isle of Doggers, from the fourteenth-century fishing vessels known as doggers.

The difficulty with this explanation is that there were no ports, hithes or landing-stages on the land embosomed by the curve of the river. ${ }^{2}$ There was nowhere for a fishing vessel to call in, or for fishing vessels to congregate, unlike on the southern side where there were hithes at Greenwich and Deptford. Also, there is no evidence that the land was ever called Isle of Doggers by anybody.

5. That there were either wild dogs there, or dead dogs washed up by the tide there.

We have no way of knowing whether either of these were true, or more true of this part of the Thames than any other.

6. That Isle of Dogs alludes to the Canary Islands, because Latin Insulae Canariae means 'island of dogs'. The historian Pliny says that these islands were so-named because there were large dogs there.

This hypothesis lacks evidence or circumstance that would make this likely. Canary Wharf appears not to have become

${ }^{2}$ I thank an anonymous reviewer for pointing out that the name Stepney, earlier Stebbenhithe (and spelling variants) implies a hithe or landing-stage. However it is not thought that the hithe in question was situated on the marsh, but at Ratcliff Cross, in present-day Limehouse: "Evidence for Saxon settlement is etymological. The first reference to Stepney is to men of the bishop of London's estate (vill) of Stybbanhythe c. Iooo, recording a hithe or landing-place either on the Thames or the Lea. Since the place-names Old Ford and Stratford are associated with the Lea, while the name Stepney has always been linked with the southwest quarter of the parish, the hithe was probably on the gravel at Ratcliff Cross, one of the few sites below London Bridge suitable for landing before the marshes were embanked and wharfed.” (Baker (ed.) I998: I3-19). 
so-named until I936, when the shipping company Fred Dessen $\&$ Co., which unloaded fruit from the Mediterranean and Canary Islands, was granted permission to rename the wharf known previously as West Wood Wharf. ${ }^{3}$

I conclude that none of these explanations really holds water, with no supporting evidence for any of them.

\section{Early attestations of the place-name Isle of Dogs}

The name Isle of Dogs is first attested in I 520 . Before I 520 , the place we know as the Isle of Dogs was called Stepney Marsh, for which Mills (200I: I2I) has a first attestation date of I365. Stepney Marsh is relatively well documented: there exists a field survey of the marsh from around I 400 , and also wills of several landlords who bequeathed land in Stepney Marsh to their heirs in the late Izoos and early I 400 . There was a settlement in the marsh from at least the second half of the twelfth century; the manor house at the southern end, somewhat inland from the sea-wall, was owned by William de Pontefract, and his manor house, chapel and the hamlet around became known as Pomfrets, ${ }^{4}$ which manor was ultimately owned by the Bishop of London (Cowper I 853: I6). However this place-name did not last. The manor house was in ruins by the 1360 , and the hamlet was abandoned in 1448 when the river burst through the sea-wall (Dugdale I662: 72). It seems that the manor of Pomfret became abandoned because of partible inheritance, as none of the descendents of William de Pontefract actually lived at Pomfrets or maintained it or the sea-walls (Currie (ed.) I998: I $-7,52-63)$.

Further place-names of Old English etymology in the marsh are as follows. At the northern perimeter of Stepney Marsh the long street village of Poplar ${ }^{5}$ runs from foreshore to foreshore, with the lime kilns

3 'The West India Docks: The buildings: warehouses', Survey of London: volumes 43 and 44: Poplar, Blackwall and Isle of Dogs (I994), pp. 284-300. URL: http:// www.british-history.ac.uk/report.aspx? compid=46497\&strquery=west india docks buildings war. Date accessed: 06 December 2012.

4 'The Isle of Dogs: Introduction', Survey of London: volumes 43 and 44: Poplar, Blackwall and Isle of Dogs (I994), pp. 375-387. URL: http://www.british-history. ac.uk/report.aspx? compid=46507. Date accessed: 06 December 20 I 2.

5 AN popler 'at the poplar tree', Gover, Mawer, Stenton I942: I33-I34. 
of Limehouse at the north-western point of the curve ${ }^{6}$ and Blackwall at the north-eastern point. Moving south around the curve, the western embankment of Stepney Marsh was called Westwall; $;$ the north-eastern embankment was called Blakewalle, present-day Blackwall (after which the hamlet was named) ${ }^{9}$ and some, or perhaps all, of the embankment round Stepney Marsh was called Themsewall and Longewall. ${ }^{\circ \circ}$ Further dwellings in the marsh were situated at Westwall and at Newebygynge. ${ }^{\text {I }}$

From various wills we learn that the marshland was called Stebbenhith mersche; Stebbenhithmerssh; ${ }^{\mathrm{I2}}$ that fields in the marsh were called Margarusagre atte gate, 'Margaret atte Gate's acre', ${ }^{13}$ Potterisfeld, 'Potter's Field' and Chafcroft, 'Calves' Croft'. ${ }^{\mathrm{I} 4}$ We learn that there was a bridge or jetty called ffisshbregge; and that the chapel at Pomfrets was dedicated to St Mary and All Saints in the marsh: Beate Marie \& Omnibus Sanctis, ${ }^{15}$ Beate Marie de Capelle in le Merssh, ${ }^{16}$ Capelle Beate Marie in Marischo. ${ }^{17}$ From the Stepney Field Survey of c.I400 ${ }^{18}$ we learn that ffysshysbregge, ffysshysfeld and ffysshyslond were owned by Thomas ffyssh; that Thomas Edewyne had three rods of land lying by the wall called Thameswall; and that John Hamme had one rod lying above le Throwedych. ${ }^{19}$ The names of hills, fields, walls, enclosures,

${ }^{6}$ Gover, Mawer, Stenton I942: I 50; OE lìm 'lime' + OE āst 'oast, kiln'.

7 Gover, Mawer, Stenton I942: I35; presumably OE blǣc 'black' + OE weall 'wall, rampart of earth or stone'.

${ }^{8} \mathrm{Kew}, \mathrm{TNA}, \mathrm{SC}$ I $2 / \mathrm{II} / 3$ I fo I $2 \mathrm{v}$.

$9 \mathrm{Kew}, \mathrm{TNA}, \mathrm{SC}$ I $2 / \mathrm{II} / 3$ I fo I $6 \mathrm{v}$.

ro Kew, TNA, SC I2/II/3 I fos I7V and I9. Cowper (I 853:4), discussing process of building these medieval embankments, writes "With might and main they toiled, and by might and main they overcame".

I Kew, TNA, SC I 2/I I/3 I fo I 2. "wall vocata Newebygynge" - which might indicate ongoing embanking work as bigging meant both 'dwelling' and 'building' (see OED bigging, $n$.).

I2 E.g. I404; London Metropolitan Archives DL/C/B/O04/MSo9I7I/002, fo 54V; Will of Roger Grummote.

I3 I 376, LMA DL/C/B/004/MSo9I7I/002, fo 36v. Roman type indicates expansion of abbreviations and place-names have been given initial capital letters.

${ }^{14}$ I3 80, LMA DL/C/B/o04/MSo9I7I/002, fo 7I; Will of Williamo pottere de maresco de Stebunhith.

is I3 80, LMA DL/C/B/004/MSo9 I7I/002, fo 7I.

${ }^{16}$ I 402, LMA DL/C/B/O04/MSO9I7I/OO2, fo 26; Will of John Broun of Stebbenhith.

17 I 405 , LMA DL/C/B/004/MSo9I7I/002, fo $5 \mathrm{IV}$.

${ }^{18} \mathrm{Kew}, \mathrm{TNA} \mathrm{SC} / \mathrm{I} 2 / \mathrm{II}_{3} \mathrm{I}$. I have tried to restrict this list to features in the marsh alone, but it is possible that a few may have lain further north. See Croot (I997) for a description and discussion of the Stepney Field Survey.

I9 Kew, TNA SC/I2/I I/3 I, fos I7v, I 8 . 
ditches, weirs, hedges, bushes and meadows in the marsh recorded in the Field Survey were:

I have counted 74 place-names in Stepney Marsh in the late I 300 s and I400s, but no mention at all of the name Isle of Dogs. If the name had been in use then, one might expect it to show up in these detailed sources. But it does not.

Table 1. Names of hills, fields, walls, enclosures, ditches, weirs, hedges, bushes and meadows in Stepney Marsh (Field Survey of Stepney, c.I400, TNA SC/I2/II/3I).

fo I I Sandhell, Battysfeld

fo I Iv Westwall, Westyerde, Kalfstokkysfeld, Pylyslond

fo I 2 Sonderesffeld, Sondereslond, Sonderesthrowe, Wall vocata Newebygynge, Amystonerffeld, le Chekyr

fo I 2v Cochysgate, Worlycheslond, Sandhell in South Newelond, Codyneshawe, Kalstokkyslond, Kalstokkyswere, Chapell Lond, Rodeberdeslonde, Coughdesyerde, Long Acre, Karles Acre, Breweresyerde, Schypmade, Gattyswere, Goldyngeslond, ffanneresmade (belonging to Henry Vannere), Shyftylcroft

fo I4 le ffanneresmade apud le Wylde

fo I 5 Byllokysland, Northbroke, Elderbussh, Scottysacre, Longemade, le Hyedoune, le Netherdoune iuxta le Hye doune, Crepyneslond in le Hyedoune, Wowehegge

fo I7v Rancesfeld, Rysshcroft par le Rance, Themsewall, Deleswey, Admondeslond in Estnessh

fo I 8 Le Throwedych in Gabelond, Admondeswere, Madehawys, Deleslond, Boleyffeld

fo I9 Nethyr Somerlase, Nokysfeld, Byllokyswere, Southawys, Wereye, Madeye, ffleecroft, Longewalle iuxta Madeye

fo I9v Southmadeye, Schatffletebregge, Chynham

fo 20 Brademade, Sandhell in Brademade, le Longeforlond, Est Bryzt Onelond, Colmansyerde

fo $20 \mathrm{v}$ Wyseffletdych, Rowynglond, Thornhegge

fo 2 I Chalfcroft, Grandylhope, Bradecroft in le Hooke

fo 2 Iv Pareshawe apud Pomffret

fo 22 Buntynglond, Smythlond 
We next turn to some information provided by Sir William Dugdale in his History of Imbanking and drayning of divers Fenns and Marshes of 1662 :

Upon an inquisition taken in $27 \mathrm{H}$. 6. the Jurors presented, that by the violence of the tides upon the banks of Stebenhithe marsh, a great part of the said banks, adjoining to that marsh, was then ruinous and broken through the neglect of the Land-holders there: And that through the default of one Iobn Harpour Gentleman, in not repairing his bank, opposite to Deptford Strond, there was, on the Monday, being the Feast of the Annunciation of the blessed Virgin, in the 26 year of the reign of the said King H. 6. a breach made in the said bank of the before-specified Iohn Harpour, for the length of $x x$ Rods, unto the land of Iohn Fyloll, in so much as a thousand Acres of land, lying within the said marsh, were drowned.

(Dugdale I662: 72)

It is significant that the 26 Henry 6 (I448) breach of the banks occurred opposite Deptford Strand, because in I 520 the place-name Isle of Dogs occurs, also referring to a specific area of Stepney Marsh opposite Deptford Strand; specifically, opposite the Royal Dockyard at Deptford. It is in The Boke of thaccoumptte of Costys Ande Charges don 6 made on the Kinges Schyppes for the transportynge of the kinge 6 the Qwen to Calyce to the metynge of the frensche kinge \& from thence in to Inglond Ageyn..$^{20}$ This is the accounts-book of Henry VIII's Dockyard at Deptford, where warships were built and repaired, and which had been in existence for seven years in 1520 . The place-name Isle of Dogs is mentioned as a berth:

" \& to John holmes for a hose for the mary George lynge in at doke at theille of dogges afor depford xd"

(October I520; Kew, TNA MS E 36/II, fo II7v, calendared in Letters and Papers of Henry VIII, volume 3, pp 369-38I)

The location of theille of dogges is 'afor depford' (the word opposite was not available, as it did not carry its present meaning at this date, see Wright 2006). The same ship, the Mary George, was again berthed in the same place five years later:

"vppon theEste side of theile of doggis"(theleafis damaged here sothere is no more context) ... "Item the Mary george beinge of portage / ijC \&

${ }^{20}$ Kew, TNA E 36/I I, fo Io4; 'Calyce' is Calais. 
L tonne / lythe / vppon the sowthe syde / of the Ile of doggis / and muste be Calkyd / wine the borde \& $\mathrm{w}^{\mathrm{t}}$ oughte / also she must be seerchyd for wurmehoolys because she hath ben in leevaunte /" (October I 526; London, British Library Cotton MS Otho E IX, fo $68^{21}$ calendared in Letters and Papers of Henry VIII, volume 4, pp 757-772)

\section{Early map evidence}

The first map to show the place-name Isle of Dogs is Robert Adam's map Thamesis Descriptio, of 1588 , which shows the lower reaches of the River Thames below the Pool of London. ${ }^{22}$ Robert Adam was Surveyor of Works to Queen Elizabeth I. His map was made as part of the response to the Spanish Armada, the Secretary of State for War having asked what arrangements had been made for the defence of the kingdom. It shows the river as seen from on board a vessel, plus the army's camp further inland at West Tilbury. The map demonstrates, by means of arcs of sweeping lines, the rakes of gun-fire possible from the defences positioned on the riverbank. There are tiny horses and riders depicted on the causeway from Tilbury Fort to the camp "beset wth twentye \& seven ensigns", and rowbarges and small boats at the barrage or boom between Gravesend and Tilbury Fort. Two batteries are shown upriver on either side at Lee Ness on the south bank and Saunders Ness opposite on the north (Saunders Ness lies on the eastern side of Stepney Marsh). These are the first marked defences downriver from London, and there is another boom across the river at this point. The river seems well defended, but the effort was not, in the event, necessary, as the Armada was blown off course and never attempted to attack London.

The careful labelling of this map deserves a fuller treatment. ${ }^{23}$ There are three types: labels written perpendicular to the river, labels written horizontally to the river, and labels written in the river. The first group contains natural features of the riverbank which enable that part of the bank to be identified visually from onboard ship, with two non-natural

${ }^{21}$ See State Papers Online database:

http://go.galegroup.com/mss/i.do?id=GALElMC430I00I 776\&v=2.I \& $\mathrm{u}=\mathrm{cambuni} \& \mathrm{it}=\mathrm{r} \& \mathrm{p}=$ SPOL\&sw=w\&viewtype $=$ Calendar

${ }_{22}$ London, British Library, Adds MS 44839.

${ }^{23}$ I am particularly grateful to Prof Derek Keene for drawing my attention to the significance of the orientation of the labelling. 


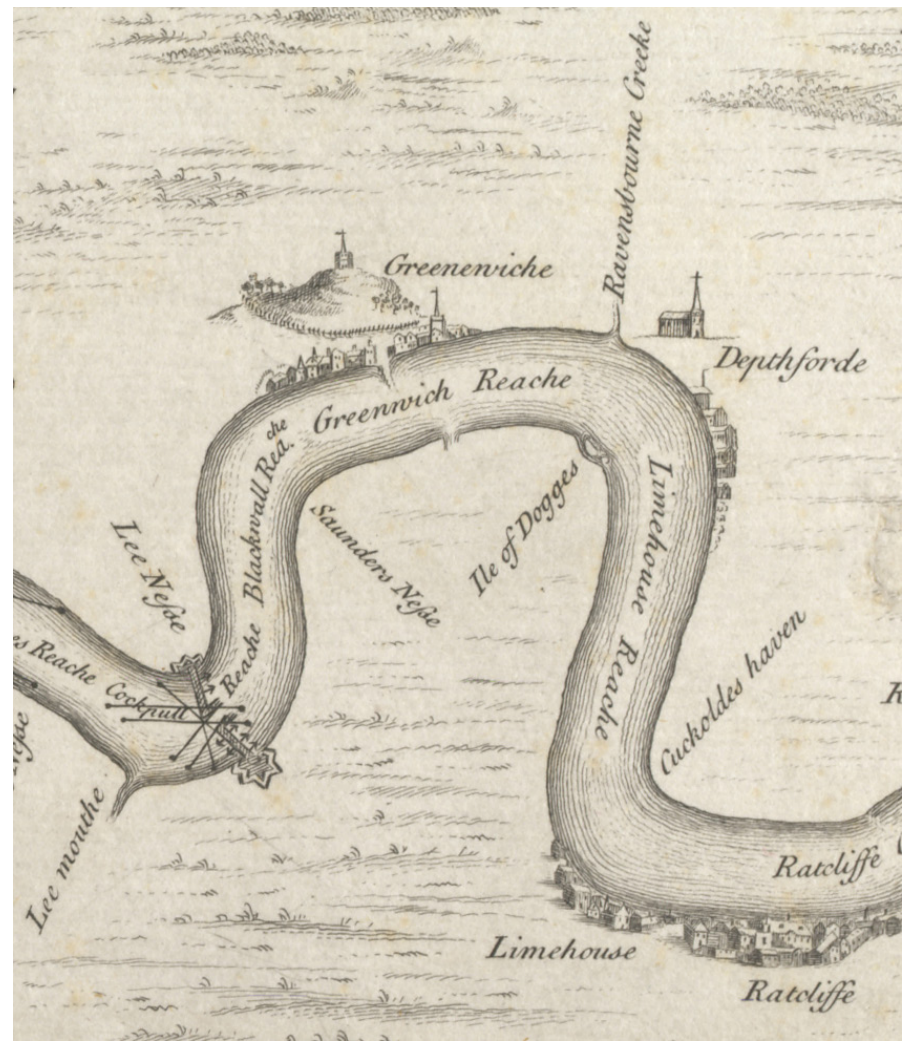

Thamesis Descriptio Anno I588, surveyed by Robert Adams, I738. Crace Collection, British Library. Reproduced with permission. (Note: this is a different map to the one described, the same in all essentials but with shipping omitted and slightly different spellings).

(source: http://www.bl.uk/onlinegallery/onlineex/crace/t/largeimage88364.html)

exceptions (Gallion and Tripcotts, the names of riverside buildings in what was otherwise featureless marsh). Head-nouns are breache, creeke, elmes, haven, ile, mouthe, nesse, pointe, tree. The second group, written horizontally to the river, contains place-names. The third group, written in the river, contains the names of stretches of the river that could be viewed from bend to bend. Head-nouns are checke, hope, poole, reache.

Group One, written perpendicular to the river, grouped alphabetically according to head-noun, contains:

Ye Litle Breache

Ye greate Breache

Stackie Breache 
Barkinge Creeke

Daignâ Creeke

Dartfoorde Creeke

East Ham Creeke

Rainam Creeke

Rauensborne Creeke

Podds elmes

Saunders elmes

Ile of Dogges

Cuckolds haven

Leemouthe

Brode Nesse

Crosse Nesse

Erithe Nesse

Gallion Nesse

Greenhith Nesse

Hooke Nesse

Lee Nesse

Magott Nesse

Northfleete Nesse

Saunders Nesse

Staffleete Nesse

Stone Nesse

Theeves Nesse

Tilberie Nesse

Gilian tree pointe

Middway tree

Gallion

Tripcotts

Saunders Elmes and Podds Elmes are marked by trees. Gallion and Tripcotts are marked by small buildings. The breaches are marked by lesser or greater pools, and the creeks are marked by tributaries entering the river. The features labelled with Group One names all act as 
checkpoints in otherwise featureless marsh, either distinguishing one reach of the river from the next, or helping to identify that particular reach. They are navigational aids, especially necessary in darkness or foggy weather.

Group Two, written horizontally to the river, and looking downstream from Westminster, contains place-names:

Westminster, Lambeth, London, Southwarke, Raderife, Ratcliffe, Limehouse, Depthfoorde, Greenewiche, Woolwiche, Erithe, Rainam Marshe, Pourfleete, Stone, St Clementes, Greenehithe, Graies, Northfleete, Grauesende, Tilberie forte, The Campe, Grauesende forte, the olde Blockhouse (marked thus on both sides of the river), East Tilberie, Cliffe.

Group Three labels are written in the river, looking from downstream from London:

the Poole

Ratcliffe Checke

Limehouse Reache

Greenewiche Reache

Blackwalle Reache

Cockpull Reache

Podds elmes Reache

Woolwiche Reache

Gallion Reache

Tripcott Reache

Crosse Nesse Reache

Erithe Reache

Maese

Longe Reache

St Clements Reache

Northfleete Hope

Grauesende Reache

Tilberie Hope

These short stretches of river from bend to bend enable the sailor to identify his position at any one point.

There are two labels written on Stepney Marsh: Saunders Nesse at the south-eastern point of the curve and Ile of Dogges at the southwestern point. The $I$ of the label Isle of Dogges is located right next 
to two small islands in the breach opposite Deptford. Both labels are written perpendicular to the river, aligning them with features of the riverbank that could be identified from on board ship as aids to navigation. They are both identifying features, a ness and an isle, in otherwise uninterrupted marshland. It might be argued that there is little room on Stepney Marsh for a label to be written horizontally, and that therefore the certain identification of the label Ile of Dogges with the two small islands, rather than the mainland, is not secure. However this is also the case with what appears to be an anomaly in Group Two, Rainam Marshe, which, being a natural feature of the riverbank, might be thought to sit better in Group One. However, Rainam Marshe is not an identifying feature - all the foreshore from the estuary up was lined with indistinguishable marshland. This particular marsh is named because it is depicted as an island, created by a small channel slicing the tip of Erith Ness from east to west. The perpendicular label Erithe Nesse (the identifying feature) intersects the horizontal label Rainam Marshe (the place-name) at right angles. Similarly, the perpendicular label Greenehithe Nesse (the identifying feature) intersects the horizontal label St Clementes (the place-name) at right angles. The feature salient to shipping - in this case, the ness or bend of the land - is clearly differentiated in each case from the place-name. Had Isle of Dogs been a marsh place-name, it could have been positioned horizontally so as to intersect the label Saunders Nesse, just as the horizontal label Rainam Marshe has been positioned. But it was not, and therefore has to be interpreted as marking the two small islands.

Lastly, let us consider the shipping in the river. There are four separate groups of ships depicted, at the Tilbury Fort/Gravesend boom (4 or 5 rowbarges and several small boats), Ratcliffe Checke (9 ships), the Pool ( 5 ships), and just upstream of London Bridge ( 3 large vessels, 6 small). The only other vessel to be depicted is a three-masted ship in the river between Deptford and the Isle of Dogs islands.

Recall the Field Survey of c.I400, where two island names were mentioned on folio I9, Wereye and Madeye. These are presumably derived from Old English wer $+\bar{\imath} e g$, 'Weir Island' and mæed $+\bar{\imath} e g$, 'Mead Island'. There are only two island names mentioned in the Field Survey and I speculate that they are the pre-I 520 names of the two eyots afore Deptford, bestowed by those who worked in the marsh, catching fish in weirs and farming sheep on meadows. Eyots in the Thames are not permanently fixed entities but shift in shape and position over time, and can be unified at low water yet divided into two or more at high water. 
Therefore a name of Isle of Dogs for two eyots is not inappropriate: the Thames eyots upriver at Brentford now collectively known as Brentford Eyot currently fit this description. ${ }^{24}$ The foreshore opposite Deptford at this point in the curve is particularly shifting and unstable, ${ }^{25}$ and the two Stepney eyots have since disappeared, but B. H. Cowper records that the two eyots were positioned where Messrs Ferguson's mast-pond was situated in 1853 , on the south side of the pond adjoining Tindall's dock and the mast house (Cowper I853: I7) "which pond is an indentation of the river bank, and called Drunken Dock". Apparently one of the eyots was still there at that time. This mast pond was directly opposite the King's Yard at Deptford (Cowper I 853: I9).

To recap so far: the place-name Isle of Dogs referred originally not to Stepney Marsh, but to two small islands lying in the river in a breach on the Stepney side opposite Deptford. The eyots may not predate $\mathrm{I} 448$, which was when the river flooded that part of the marsh (they may have resulted from that inundation), and are likely to have been known to marsh-dwellers as Wereye 'Weir Island' and Madeye 'Mead Island' between I448 and I 520 . The dating and the context make it likely that the name or nickname Isle of Dogs was bestowed by workers in Deptford Dockyard, as they were the ones who created a dock out of the Stepney Marsh eyots. In which case, what do we know about the ships that were berthed at this place at this point in time? Can the Mary George and her ilk tell us anything about the Stepney Marsh dock?

\section{Early Ships at Deptford}

We return to the Book of Accounts of the King's Ships where the name Isle of Dogs is first mentioned:

"Here Aftyre Ensuythe All Suche Costys Chargys \& sundry expenses hade made $\&$ done by the Commaundement of the kinge owre moste drade soueren lorde henry the viij from the xijth daye of marche in the xjth yere of his moste nobull Reyngn of fore and apon the kinge is grette barke the lesse barke the newe barke namyd the Kateryn

${ }_{24}$ The western end of Brentford Eyot, which at high water becomes a separate islet, is known nowadays as Smith's Eyot or Lot's Eyot.

25 Information from Julian Kingston. Prof Derek Keene suggests that the name Isle of Dogs denoted the larger island, on later maps marked 'Osier Hope', rather than both of them. 
plesaunce The mary \& John $\mathrm{w}^{\mathrm{t}}$ the ij Rowbarges whiche schippes were prepared Ryggyd \& sett forthe ffor the transportyng of owre seid soueren lord to Calice and from Calice in to Inglond ageyn" (October I 520, Kew, TNA MS E 36/I i fo I05)

Table 2. The King's ships in I 525 (Sources: Loades (2002); "Names of the King's ships at Portsmouth and Thames, 22 Oct 17 Hen 8", Letters and Papers, Foreign and Domestic, Henry VIII, volume 4: I 524-I 530. Tonnage given where specified. Where tonnages vary it is because more than one figure is given in the source documents. (bark) signifies that a vessel was specified as such in the source documents.)

Henry Grace A Dieu

Great Galley

Sovereign

Gabriel Royal

Katherine Fortileza

Mary Rose

Great Barbara

Great Nicholas

John Baptist

Peter Pomegranate

Mary James

Mary George

Great Bark

Mary and John

Minion

Lesse Bark

Hulk

Mary Gylforde

Primrose

Henry of Hampton

Maudelen of Deptford

Mary Imperial

Katherine Bark

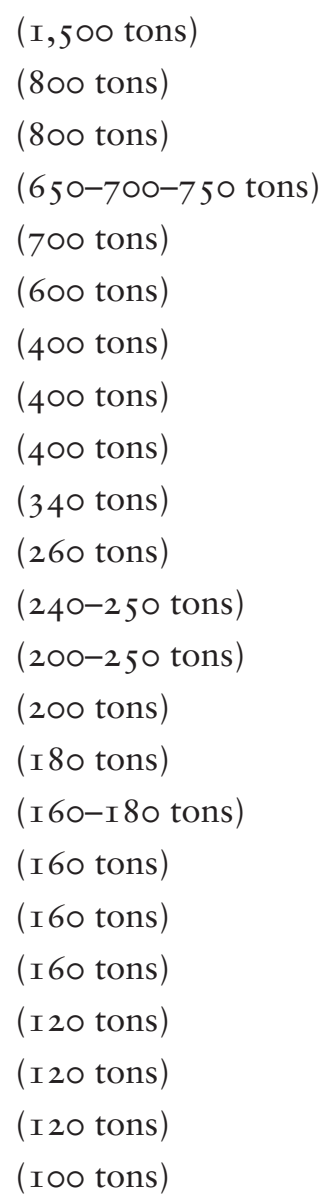


Table 2. Continued

\begin{tabular}{ll}
\hline Bark of Bullen & (80 tons) \\
Griffin & (80 tons) \\
Trinity Henry & (80 tons) \\
Sweepstake & (bark, 65 tons) \\
Bark of Murlesse (Morlaix) & (60 tons) \\
Swallow & (60 tons) \\
Great Sabra & (50 tons) \\
John of Greenwich & (50 tons) \\
Lesser Sabra & (40 tons) \\
Bonaventure & \\
Carvel of Eu & \\
Jennett of Purwyn & (bark) \\
Katherine Plesaunce & \\
Lion & \\
Margaret & (bark) \\
Mary Fortune & \\
Regent &
\end{tabular}

The king's lesser bark, his great bark, the little bark and his new bark were being repaired or built on the Thames in I $520 .{ }^{26}$ In I 495 the peacetime navy had no more than three or four ships. By I 523 it had about thirty, of varying sizes (Loades 2002: 24), as Henry VIII built up the navy. By I 525 , the following 40 of the King's ships were listed as being in the Thames, or in the Thames and at Portsmouth:

A bark was a smaller, masted, sailing vessel. If we assume that anything greater than 250 tons (the Great Bark) was not called a bark, and only include of those without specific tonnage the vessels that were explicitly named as barks, then even at this conservative estimate, more than half of Henry's fleet were known, at the time, as barks.

At this point, let us leave ships and consider other islands in the Thames. Upstream, small islands are known as eyots (Brentford Eyot, Chiswick Eyot, Isleworth Eyot, also spelt ait), from Old English ìeg

\footnotetext{
${ }^{26}$ Letters and Papers, Foreign and Domestic, Henry VIII, volume 3, October I 520.
} 
'island' with diminutive suffix -eth (OED ait, $n$., eyot, $n$., with fifteenth and sixteenth century attestations spelt le Eyte, hayte). Downstream, the far bigger islands came to be known as isles (Isle of Grain, Isle of Sheppey, Isle of Harty, Isle of Thanet). Isle is from Anglo-Norman, ultimately from Latin insula (OED isle, $n$. I. a.); ilde of Wizt is attested from CI 320 ; jlde off Tenett (Thanet) from I $473 .{ }^{27} \mathrm{I}$ argue in Wright (2010) that the Thames term for a tidal eyot found at tributaries' deltas was a horse (e.g. Fobbing Horse, Upper Horse, Lower Horse, Wodeham Horse, Sea Horse, Wyllyspitt Horse and perhaps Horse End and Horsleydown) from OE horsc 'mud'. I have speculated that the traditional names for the islands opposite Deptford were Wereye and Madeye, and we might also reasonably expect these islands to have been known collectively as Stepney Eyot. Instead, the name Isle of Dogs occurs, in the context of ship-building and dock-working. To return to the barks, I wonder whether this is Tudor dockers' word-play. The grandiose downstream Isle of - has been applied bathetically to very small islets, and the name Dogs bestowed as a pun, the eyot at Stepney harbouring barks.

Does this hypothesis fit what we know of the word bark? OED bark I barque, $n .2$ derives bark 'small ship with sails' as being "possibly from Celtic"; "a small vessel with sails; the latter was the sense with which the word was taken from French into English". The first attestation in English is by Caxton in I 477. OED bark, n. 3 derives bark 'the sharp explosive cry uttered by dogs' from the Old English verb beorcan 'to bark'. The first written attestation of the noun is not, according to the dictionary, until I 562, but this need not detain us as the attestation is poetical (literature being the text-type most thoroughly scrutinised). As the verb is Old English, the noun could have been derived at any point in the language's history. The present-day quasi-archaic spelling barque is a red herring: a search of the Early English Books Online database reveals that in the sixteenth century the spelling was always bark(e, with the -que spelling an innovation of later centuries.

That the pun was possible does not mean that it was certainly the origin of the place-name Isle of Dogs, of course; it merely raises the possibility. We next hear of the place-name Isle of Dogs on John Norden's map of Middlesex of I 593. This is a map of the whole of Middlesex and so the area is necessarily small and lacking in detail, but two parallel horizontal streams are drawn east-west on Stepney Marsh so as

${ }_{27}$ Note that the 'island' element in Canvey Island seems to postdate the period under discussion here. It is attested as Canwaie Iles in I 586 (Reaney I935: I48). 
to cut the marsh into two horizontal bands, with a meridional stream flowing north-south between the lower horizontal stream and the Thames, and another smaller north-south stream at Saunders Ness (neither Stepney Marsh nor Saunders Ness is so labelled on the map). Four labels appear in the marsh, with three symbols identified in the key. The labels are Stepney at the far north, identified with the symbol for a parish; Limehouse in the north-west and Blackwall in the north-east, both identified with the symbol for "Hamletes or villages"; and Isle of doges ferm, the lettering printed in the middle of the marsh but the identifying symbol placed precisely where Pomfrets was previously situated. This symbol, the key informs us, indicates "Howses of Knightes, Gent. \&c.", and indicates that by I 593 the place-name Isle of Dogs had superseded the place-name Pomfrets for the gentleman's house and hamlet situated on the inland part of Saunders Ness. It does not follow that the whole of Stepney Marsh had become known by that name at that date. In fact all the evidence accrued so far indicates that Stepney Marsh was still known as Stepney Marsh until at least I600 (and indeed considerably later).

\section{On London Workers' Word-Play}

If the punning explanation of the place-name Isle of Dogs suggested in Section 4 is correct - and we will never know, but it does fit the facts, which no explanation has done hitherto - then dockers' word-play goes back at least to the days of the Tudors. That there is ample evidence that writers of Tudor literature enjoyed word-play perhaps needs no elaboration here. ${ }^{28}$ But what about Tudor dock-workers? We cannot

${ }^{28}$ I leave it to the reader to decide whether both senses of bark are operative in Shakespeare's Sonnet 80 (I609):

O how I faint when I of you do write,

Knowing a better spirit doth vse your name, And in the praise thereof spends all his might, To make me toung-tide speaking of your fame. But since your worth (wide as the Ocean is) The humble as the proudest saile doth beare, My sawsie barke (inferior farre to his) On your broad maine doth wilfully appeare. Your shallowest helpe will hold me vp a floate, Whilst he vpon your soundlesse deepe doth ride, Or (being wrackt) I am a worthlesse bote, He of tall building, and of goodly pride.

Then If he thriue and I be cast away, The worst was this, my loue was my decay. 
know whether they too created puns. However, we do know that there has in more recent centuries been a tradition of London workers using word-play as an integral part of their working day. I give by way of illustration here a counting system ${ }^{29}$ long in use between (although not limited to) importers, wholesalers and retailers in the fruit trade:

Table 3. Fruiterers' counting terms, London, $20 \mathrm{I} 2$.

\begin{aligned} & \hline I Cherry \\ & 2 Bottle \\ & 3 Carpet \\ & 4 Rofe/Sugar \\ & 5 Ching \\ & 6 Tom \\ & 7 Nevis \\ & 8 Garden \\ & 9 Clothes \\ & I0 Cockle \\ & 20 Apple \\ & 25 Pony \\ & 500 Monkey \\ & \hline\end{aligned}

Some of these terms are demonstrably over a hundred years old and must speak to continuity of usage from father to son. Henry Mayhew attests to numbers four and seven pronounced backwards: "I'll try you a "gen"” (shilling), said a coster; 'And a "rouf yenap"' (fourpence), added the other." (Mayhew I 85 I: I I $7 / 2$, cited in OED rouf, adj. and $n$.; see also neves adj. and n.). OED marks headwords rouf and neves as 'now rare' and 'obs. rare', although they have subsequently been common in the spoken functional variety of market traders..$^{3 \circ}$ Carpet, from rhyming carpet bag with drag (OED carpet n. II. 6.; carpet bag n. 2 ; drag $n .8$ b.), presumably postdates 1830 when carpet bags were in vogue, but is in reference to drag in the sense 'stretch of imprisonment', attested from $\mathrm{I} 78 \mathrm{I}$. The sense development is from drag 'handcart'

${ }^{29}$ Kindly provided by Mr Steve Roberts of Westminster Produce, who is a thirdgeneration Covent Garden fruiterer.

30 Sugar must have come later than rouf as sugar loaf rhymes with [rəof]. 
to "The drag, is the game of robbing carts, waggons, or carriages.of trunks, bale-goods, or any other property. Done for a drag, signifies convicted for a robbery of the before-mentioned nature" (James Hardy Vaux A Vocabulary of the Flash Language, I 8I9) to Henry Mayhew's "Sometimes they are detected, and get a 'drag' (I85I: I. 2I9/2), in reference to the length of the term of imprisonment, which seems to have been at first six, then three months. Monkey, '500', first occurs in St James's: A Satirical Poem, in Six Epistles to Mr. Crockford, by someone writing under the pseudonym of 'Westminster St James', first published in London in I 827 . The subject is aristocrats gambling away the family inheritance at Crockfords gambling club, so that their children, the heirs, are ruined by the losses of the father. The poem mentions an Earl losing 'ten or twenty ponies' and a footnote explains: "It is not every reader that is aware of the modern title by which, in the Clubs, certain sums of money are recognised. A pony is $£_{25}$, a rouleau $£_{50}$, and a monkey $£_{500}$. The noble Earl in question, who is gifted with two sons, partaking very largely of the latter quality, was accosted by a friend at Crockford's one evening, (when His Lordship had been a loser,) who thought him looking very much out of humour, and asked the cause. 'I have lost a monkey,' replied the Earl.” (OED monkey, n. IV. 23; St James I 827: I34). Pony, '25' (pounds, guineas or sovereigns), is first attested in a novel of $\mathrm{I} 797$ by Mary Robinson, and again the meaning is made clear in a footnote: "There is no touching her even for a poney. [Note. Half a rouleau or twenty-five guineas]." (OED pony, n.I and $a d j$. 3.; Robinson I797: II, 97). Although I can find no specific supporting evidence or previous discussion, ching 'five' would seem to be derived from Anglo-Norman cinq, surviving along with ace, deuce, trey, quatre, sise, still in use (or in use until very recently) in the context of card-play (OED cinque I cinq, $n.),{ }^{3 \mathrm{I}}$ and in Channel Islands French. The relevance for our present purposes is that the counting system (or parts thereof) must have been used over several generations in an entirely non-literary, working context. It does not constitute proof that Tudor dock-workers did the same, of course, but it gives a measure of plausibility to the suggestion that they might have done so.

${ }^{31}$ For the palatalisation of the first phoneme, cf. ME chiche 'chickpea' $<\mathrm{AN}$ chiche $<\mathrm{L}$ cicer (OED chich, $n$.). Jerriais chîn, chînq 'five'. 


\section{Jonson and Nashe's play Isle of Dogs}

In the summer of I 597 the place-name Isle of Dogs achieved some kind of notoriety, but it is unclear why. The playwrights Ben Jonson and Thomas Nashe (and perhaps members of Pembroke's company) wrote and performed, but did not publish, a satirical comedy called The Isle of Dogs (www.lostplays.org; Donaldson 20I2: IOI). As a direct result, Jonson and two members of the company were imprisoned, and Nashe fled into hiding. Donaldson (201 2: I03-IO7) reconstructs events: in late July or early August, the Queen's inquisitor, interrogator and torturer Robert Topcliffe was instructed by the Privy Council to discover the instigators and perpetrators of the play, and to seek out all copies and their owners. Nashe could not be found, but Jonson and his two fellow players were arrested and imprisoned. They were examined on $15^{\text {th }}$ August by the Privy Council Court at Greenwich, and accused of "lewd and mutinous behaviour," ${ }_{32}$ the play containing "very seditious and slanderous matter". It is likely that they were tortured, but seven weeks later, on 8th October I 597, the three men were set free. Simultaneously, although it is not clear whether the two events were related, the Lord Mayor and Court of Common Council requested on 28th July I 597 that the Privy Council ban all theatrical activity, it being to the detriment of the well-being of the citizens (the Corporation of London had made similar requests on previous occasions). The same day, the Privy Council banned all plays in London throughout the summer, and ordered that theatres be dismantled - although it seems that the second part of this edict was not carried out. Was this prohibition a response to recent productions of The Isle of Dogs at the Swan playhouse? The impresario Henslowe recorded a memorandum on roth August that the current restraint was "by the meanes of playinge the Jeylle of Dooges",33 so he seems to have thought that it was. Donaldson (2012: I06) summarises the speculations of literary historians about who, exactly, might have found the play offensive. Individuals have been suggested, ${ }^{34}$ but Donaldson suggests that the severity of the response seems too great to have been triggered by an attack on a mere individual, and suggests that it may have touched upon matters of national defence (20I 2: I07).

\footnotetext{
32 lewd meant 'evil, wicked, unprincipled' in this context; see OED lewd, adj. 5.

33 http://www.lostplays.org/index.php/Isle_of_Dogs,_The. Jeylle of Dooges = Isle of Dogs.

34 The King of Poland, the late Lord Chamberlain (Donaldson 201 2: 106, and references therein).
} 
Following Donaldson's suggestion, if we take the phrase 'Isle of Dogs' to have conveyed a meaning of something along the lines of 'place where warships were fitted out', then the question follows, what was happening to shipping that summer? Wernham (I994: I43-I90) describes in detail the movements of the fleet. The Queen's main priority that year was to prevent the Spanish armada ${ }^{35}$ from attacking Britain. At the beginning of I 597, relations with France were "about at their lowest" (Wernham I994: I46), and her two counsellors Sir Robert Cecil and the Earl of Essex were quarrelling with each other. There was rebellion in Ireland, which rebels (it was feared) might seek help from Spain, and the wheat harvest was failing. National security seemed greatly threatened. Elizabeth was persuaded that her best form of defence was attack, and on Ioth March, she made Essex Master of the Ordnance. However it was not clear during the spring what his commission would be - whether to attack the armada at Ferrol, to put down the rebellion in Ireland or to attack Calais - and it was not until 9th May that the Privy Council wrote to the Lords Lieutentant and Commisioners of Musters instructing them to mobilise troops for service abroad. In early April, a plan was made to fit out two fleets. The first would lie off the Spanish coast and intercept the armada. The second fleet would follow, and be the striking force. But Elizabeth delayed, and withheld her permission until the 2oth May. Immediately thereafter, during the end of May, 28 ships of war were fitted out, plus around 30 flyboats to transport troops..$^{36}$ The two-fleet plan was dropped and consolidated into one 'powerful strike force', with Essex in command.

Essex's commission had been sealed on 4 th June, that is, $4^{\text {th June }}$ is the date from when it could have been known that a war fleet was being assembled. He received his detailed instructions privately on 15 th June: he was to destroy the armada then lying at Ferrol, and afterwards sail to the Azores to intercept the Spanish treasure ships where they revictualled on returning from the East and West Indies, and to return home by winter. He was forbidden to attack either Spain or Portugal. Essex's fleet finally set out on Ioth July, but a week of storms caused half the fleet to return, leaking and damaged. The other half

35 Known as the Ferrol armada, from where it spent the summer of 1597.

${ }^{36}$ Cadwallader (I923: 5) specifies 38 vessels and troop-carriers, plus 5/6 small vessels with each of the 4 squadrons, plus 20 voluntary barks on the look-out for plunder. The discrepancy arises, I think, due to differences in classifying the smaller ships. 
Table 4. Ships of the I 597 Islands Voyage fleet. (Sources: Wernham (I994), Gorges (I625), Cadwallader (I923). Dating and construction information taken from Colledge and Warlow eds (2006), http://en.wikipedia.org/wiki/ List_of_ship_names_of_the_Royal_Navy.)

\begin{tabular}{|c|c|c|c|}
\hline Ship & Where built & When built & Rebuilt \\
\hline Adventure & Deptford & I 594 & \\
\hline Advice & Woolwich & I 586 & \\
\hline Antilope & & I 546 & I 577 \\
\hline Ark Royal & Deptford & I 587 & \\
\hline Bonaventure & & I 567 & \\
\hline \multicolumn{4}{|l|}{ Defiance } \\
\hline Dreadnought & Deptford & I 573 & I 592 \\
\hline Due Repulse & Deptford & I 595 & \\
\hline Elizabeth Jonas & Woolwich & I 559 & Deptford I 597 \\
\hline Foresight & & I 570 & \\
\hline Garland & & I 590 & \\
\hline Golden Lion & & I 557 & I 582 \\
\hline Hope & Deptford & I 559 & \\
\hline \multicolumn{4}{|l|}{ Marigold } \\
\hline Mary Rose & & I 556 & I 589 \\
\hline Mercury & Deptford & I 592 & \\
\hline Merhonour & Woolwich & I 590 & \\
\hline Moon & Deptford & I586 & \\
\hline Nonparellia & & I 556 & I 584 \\
\hline Rainbow & Deptford & I586 & \\
\hline Roebuck & & I 585 & \\
\hline St Andrew & Spain & & \\
\hline St Mathew & Spain & & \\
\hline Spy & Limehouse & I5 56 & \\
\hline Sun & Chatham & I 586 & \\
\hline Swiftsure & Deptford & I 573 & I 592 \\
\hline Tramontana & Deptford & I 586 & \\
\hline Triumph & Deptford & I 562 & I 597 \\
\hline Warspite/Wast Spite & Deptford & I 596 & \\
\hline White Bear & & 1563 & \\
\hline
\end{tabular}


sailed close to Ferrol, close enough that the armada could see them,

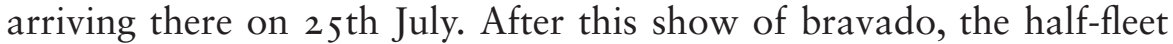
sailed back to Plymouth and regrouped on 3 Ist July. Frustrated by bad weather, Essex and Sir Walter Raleigh planned to quit Spain altogether and sail instead to the West Indies to capture treasure ships. But the Queen forbade it: defeat of the armada was the nation's first priority. On I4th August the wind changed, and the fleet duly set out for Ferrol, only to become becalmed. This is the point at which Jonson and his two collaborators were being interrogated. Looking back, on 28th July when the edict against plays and playhouses went out, half the fleet had been lying storm-damaged at Plymouth and Falmouth, and the other half had been taunting - but not destroying - the Spanish armada. In June, Elizabeth had been vacillating, and at the end of May, the dockyards had been busy fitting ships for war. We cannot know precisely when the play Isle of Dogs was written, but if it was topical, it was created and performed during sensitive times for national security. There might be evidence that it predates June IIth: an entry in the Calendar of State Papers for that date reads:

John Chamberlain to Dudley Carleton, attendant on the ambassador at Paris. ... There are great preparations for a voyage, some say for Calais, some the islands of Jersey, some the King of Spain's navy, or the Indian fleet. There are I 5 of the Queen's ships, two Spanish ships taken last year and re-fashioned, 22 Holland men-of-war, and 24 fly-boats for carriage of men and victuals. ... There is a new play of humours in great request, but it is great cry for little wool."

(Green (ed.) I 869: 437-8)

Humours at this date meant 'an excited state of public feeling'. ${ }^{37}$ If this is our play, then it was composed before June IIth, during the weeks when the Deptford Dockyard would have been fitting out the fleet for war. If national defence was the target, or perceived target, of the play's satire, as Donaldson (2012: I07) hypothesises, then against a background of such threats to national security, any criticism of

37 OED humour, $n$. II. 5. c., first attestation I 600: "It was not fitte to stirre up humours in Spaine." 
strategy, policy or capability of the fleet could have been interpreted as mutinous and seditious. ${ }^{38}$

Subsequent events are not material to the play, but if The Isle of Dogs had criticised national defence, its authors would indeed have been percipient. Never had England been allowed to be so off-guard. Essex's fleet had left Plymouth on I7th August, and again been assailed by poor weather, causing damage to some of the ships. By 27th August the fleet had been scattered and partly blown past Ferrol. Unable to sail back due to an adverse wind, Essex decided to press on and intercept the Spanish treasure fleet returning from the Indies. On 3 oth August he was misinformed that the armada had set sail for the Azores, and so the fleet arrived there in early September. Raleigh's troops caused damage to one of the islands, and Essex did manage to capture three Spanish cargoes, but on 9 th October the fleet set sail for home, arriving separately in the last week of October. They did not know that on 9th October the armada had also set sail, leaving Ferrol bound not for the Azores but for England. The Spaniards had intelligence that Essex was in the Azores and had left England undefended, and their plan was to attack Falmouth and Plymouth, then lie in wait to intercept Essex's fleet as it returned. In the event, the armada got to within 30 to Io miles off the Lizard when adverse weather set in, storms damaged the ships, and the armada returned to Coruña and Ferrol. There was no attack (Wernham I994: I 83-I90; Green (ed.) I 869: 520).

There were two further dramatic uses of the place name Isle of Dogs published sufficiently close to I 597 to constitute a possible reference to the events of that summer. The first occurs in Middleton and Dekker's play The Roaring Girl, or Moll Cutpurse, published in I6I I. As well as a pun on dogs, there is a context of knavery and fighting. The placename occurs in a conceit of sea-faring, which has nothing to do with the rest of the play, which is set in Holborn.

Moll. Souldier? thou deseru'st to bee hang'd vp by that tongue which dishonours so noble a profession, souldier you

${ }^{8}$ A trivial possibility, for example, arises from the detail of Essex's instructions on his appointment to the office of Master of the Ordinance. "We would prevent your falling into the errors of your predecessors" ... "You shall keep the quantity of stores a secret from all but our sworn servants, not using your own clerks or strangers, which has heretofore done disservice" (Green (ed.) I 869: $38 \mathrm{I}-3$ ). Apparently the previous Master of the Ordinance, the Earl of Warwick, had pilfered the stores and stolen munitions. 
skeldering varlet? hold, stand, there should be a trapdore here abouts.

\section{Pull off his patch}

Trap. The balles of these glasiers of mine (mine eyes) shall be shot vp and downe in any hot peece of seruice for my inuincible Mistresse.

Iac. Dap. I did not thinke there had bene such knauery in blacke patches as now I see.

Mol. Oh sir he hath bene brought vp in the Ile of dogges, and can both fawne like a Spaniell, and bite like a Mastiue, as hee finds occasion.

L. Nol. What are you sirra? a bird of this feather too.

T. Cat. A man beaten from the wars sir.

T. Long. I thinke so, for you neuer stood to fight.

Iac. Dap. What's thy name fellow souldier?

T. Cat. I am cal'd by those that haue seen my valour, Tear-Cat.

Omnes. Teare-Cat?

Moll. A meere whip-Iacke, and that is in the Common-wealth of rogues, a slaue, that can talke of sea-fight, name all your chiefe Pirats, discouer more countries to you, then either the Dutch, Spanish, French, or English euer found out, yet indeed all his seruice is by land, and that is to rob a Faire, or some such venturous exploit; Teare-Cat, foot sirra I haue your name now I remember me in my booke of horners, hornes for the thumbe, you know how.

T. Cat. No indeed Captaine Mol (for I know you by sight) I am no such nipping Christian, but a maunderer vpon the pad I confesse, and meeting with honest Trapdore here, whom you had cashierd from bearing armes, out at elbowes vnder your colours, I instructed him in the rudements of roguery, and by my map made him saile ouer any Country you can name, so that now he can maunder better then my selfe.

(Middleton \& Dekker, I6I I, The Roaring Girl, or Moll Cutpurse)

The place-name Isle of Dogs also occurs in Beaumont and Fletcher's Thierry and Theodoret, first published in I62I. Again, there is a pun this time on cats - and a context of quarrelling and fighting:

Enter Thierry, Theodoret, Brunhalt, Ordella, Memberge, Martell.

Thier. What villain dares this outrage? 
Devitry. Hear me, Sir, this creature hir'd me with fifty crowns in hand, to let Protaldye have the better of me at single Rapier on a made quarrel; he mistaking the weapon, laies me over the chops with his club fist, for which I was bold to teach him the Art of memory.

Omnes. Ha, ha, ha, ha.

Theo. Your General, Mother, will display himself.

'Spight of our Peace I see.

Thier. Forbear these civil jars, fie Protaldy, So open in your projects, avoid our presence, sirrah.

Devi. Willingly, if you have any more wages to earn, You see I can take pains.

Theo. There's somewhat for thy labour, More than was promis'd, ha, ha, ha.

Bawdb. Where could I wish my self now? in the Isle of Dogs. So I might scape scratching, for I see by her Cats eyes I shall be claw'd fearfully.

Thier. We'll hear no more on't, Soft Musick.

(Beaumont and Fletcher, I62I, Thierry and Theodoret, Act II Scene 2)

The place-name Isle of Dogs may have been chosen for no other reason than it allows wit about dogs and cats and was part of the zeitgeist. ${ }^{39}$ The quarrelsome contexts could be due to coincidence (quarrels being dramatic staples), or there may be some allusion here to the contents of the 597 play. Duplicity would seem to be relevant to fawning like a spaniel and biting like a mastiff. And it must be borne in mind that the I 597 play may have had nothing to do with Donaldson's suggestion of the Islands Voyage at all, as there were plenty of other sensitivities to probe.

39 Names which catch the zeitgeist can move well outside their original sphere of reference; see Wright (20II) for waterloo blue (battle I8I5, dye I823), magenta red (battle I859, dye I860), solferino (battle I859, dye c.I865), waterloo bang-up (a type of cracker, I 826), waterloo cracker (I833), trafalgar chair (battle I805, chair I 822), trafalgar cotton (I826), trafalgar coach (I848). Gibraltar rock (I83 I) and Wellington pillars (I85I) were types of sweets. In the I 860 s the name Garibaldi was marketed as the name of a type of blouse, in the $\mathrm{I} 88 \mathrm{O}$ as both a hat and a type of fish, and then from the 1890 s to the present as a type of biscuit. 


\section{Conclusion}

It now remains to sort hypothesis from fact. I have hypothesised that the name Isle of Dogs may be Deptford dockworkers' word-play on the barks berthed at Stepney Eyot. This hypothesis hinges on the two meanings of the word bark on the one hand, and the fact that the place-name is first known to us in the context of the Deptford Dockyard in I 520 , just seven years after that dockyard opened, on the other. Were further research to reveal an earlier, pre-I 5 I 3 attestation, this hypothesis would no longer stand. It is also worth emphasising that just because the pun was possible, it does not follow that it is necessarily the correct explanation. What is certain, however, is that sixteenth-century dockworkers used the name Isle of Dogs for the eyots opposite their yard, rather than for the whole of Stepney Marsh as it is known today. Therefore, whatever the contents of the lost I 597 play The Isle of Dogs, the reference may have been concerned with that dockyard in some way, if that reference were indeed topical rather than allegorical or fantastical.

\section{References}

\section{Manuscripts}

Kew, The National Archives MS E 36/I I. Accounts Book of the King's Ships. I 520. Calendared in Letters and Papers of Henry VIII, volume 3, pp 369-38I.

Kew, The National Archives, MS SC I 2/I I/3 I. Field Survey of Stepney, c. I 400. London, British Library, Adds MS 44839. Robert Adam, Thamesis Descriptio, I 588 .

London, British Library, Cotton MS Otho E IX, I 525 . Calendared in Letters and Papers of Henry VIII, volume 4, pp 757-772.

London, London Metropolitan Archives, DL/C/B/o04/MSo9171/002, wills, I $380-\mathrm{I} 405$.

\section{Printed Sources}

Baker, T.F.T. (ed.). (1998). Stepney: Settlement and Building to c.I700. A History of the County of Middlesex: Volume II: Stepney, Bethnal Green. British History Online. Web. 05 November 20I4. http://www.britishhistory.ac.uk/report.aspx?compid=22733).

Cadwallader,L.H. (I923). Career of the Earl of Essex I 597-I60 I. Philadelphia: University of Pennsylvania. 
Colledge, J.J. \& Warlow, B. (eds) (2006). Ships of the Royal Navy: the Complete Record of all Fighting Ships of the Royal Navy from the I 5 th Century to the Present. London: Chatham.

Cowper, B.H. (I853). A Descriptive Historical and Statistical Account of Millwall, Commonly Called the Isle of Dogs; Including Notices of the Founding, Opening, Etc., of the West India Docks and City Canal, and Notes Relating to Limehouse, Poplar, Blackwall, and Stepney. London: Robert Gladding.

Croot, P. (I997). Settlement, tenure and land use in medieval Stepney: evidenceof a field survey c.I400. London Journal 22:I, I-I 5 .

Cunningham, P. (I 849 edition). A Handbook for London, Past and Present. Volume 2. London: John Murray.

Currie, C. R. J. (ed.). (I998). A history of Middlesex. Vol. I I, Early Stepney with Bethnal Green. The Victoria history of the counties of England. Oxford: Published for the Institute of Historical Research by Oxford University Press.

Donaldson, I. (20I2). Note on The Isle of Dogs, lost play ( I 597). D. Bevington, M. Butler and I. Donaldson (eds) The Cambridge Edition of the Works of Ben Jonson. Volume I, I 597-I60I. Cambridge: Cambridge University Press, IOI-IO9.

Dugdale, W., Sir. (I662). The History of Imbanking and drayning of divers Fenns and Marshes, both in forein parts, and in this Kingdom. And of the improvements thereby. London: Alice Warren.

Fletcher, J. \& Massinger, P. (1679). The Tragedy of Thierry and Theodoret. London: John Martyn, Henry Herringman.

Gorges, A., Sir. (1625). A Larger Relation of the said Iland Voyage. Purchas, Samuel. Purchas his Pilgrimes. Book 4. (I938-I969). London: Henrie Fetherstone.

Green, M.A.E. (ed.). (I 869). Calendar of State Papers, Domestic Series, of the reign of Elizabeth, I595-I597. London: Longmans, Green, Reader, and Dyer.

Johannesson, N-L. (201 2). "Rihht alls an hunnte takepp der. /Wipp hise zæpe racchess": Hunting as a metaphor for proselytizing in the Ormulum. R. Dance and L. Wright (eds) The Use and Development of Middle English: Proceedings of the Sixth International Conference on Middle English, Cambridge 2008. Frankfurt am Main: Peter Lang, 229-240.

Loades, D. ([I995] 2002). From the King's Ships to the Royal Navy I 500I642. J.R. Hill \& B. McL. Ranft (eds) The Oxford Illustrated History of the Royal Navy. Oxford: Oxford University Press, 24-55. 
Middleton, T. \& Dekker, T. (I6I I). The Roaring Girle. Or Moll Cut-Purse. London: Thomas Archer.

Mills, A. D. ([200I] 2004). Oxford Dictionary of London Place Names. Oxford: Oxford University Press.

Norden, J. (I 593). Speculum Britannicae. The First Parte. An Historicall, \& Chorographicall Discription of Middlesex. Wherin Are Also Alphabeticallie sett Downe, the Names of the Cyties, Townes, Parishes Hamletes, Howses of Name \&.c. Wth Direction Spedelie to Finde Anie Place Desired in the Mappe \& the Distance betwene Place and Place without Compasses. No Place.

Reaney, P. H. (I935). The Place-Names of Essex. English Place-Name Society, volume I2. Cambridge: Cambridge University Press.

Robinson, M. (I797). Walsingham: or, the Pupil of Nature: a Domestic Story. 2 volumes. London: T. N. Longman.

St James, Westminster. (I 827). St James's: A Satirical Poem, in Six Epistles to Mr. Crockford. London: Ibotson and Palmer.

Strype, J. (ed.). (I720). A survey of the Cities of London and Westminster: Containing the Original, Antiquity, Increase, Modern Estate and Government of those Cities. Written at first in the year MDXCVIII by John Stow. London: A. Churchill, J. Knapton, R. Knaplock, J. Walthoe, E. Horne, B. Tooke, D. Midwinter, B. Cowse, R. Robinson and T. Ward. Volume I.

Wernham, R.B. (I994). The Return of the Armadas: The Last Years of the Elizabethan War against Spain I595-1603. Oxford: Clarendon Press.

Wright, L. (2006). Street addresses and directions in mid-eighteenth-century London newspaper advertisements. N. Brownlees (ed.) News Discourse in Early Modern Britain. Selected papers of the Conference on Historical News Discourse 2004. Linguistic Insights Studies in Language and Communication, Volume 30. Bern: Peter Lang, I99-2 I 5.

. (2010). A pilot study on the singular definite articles le and la in fifteenth-century London mixed-language business writing. R. Ingham (ed.) The Anglo-Norman Languge and its Contexts. York: York Medieval Press and The Boydell Press, I3O-I42.

- (20II). The Nomenclature of some French and Italian Fireworks in Eighteenth-Century London. The London Journal 36:2, I09-39.

\section{Online References}

Early English Books Online: http://eebo.chadwyck.com.

Letters and Papers, Foreign and Domestic, Henry VIII, Volume 3: I 5I9-I523 
(I867), pp. 369-38I. URL: http://www.british-history.ac.uk/report.aspx? compid=9I055. Date accessed: I 6 November 2012.

Literature Online: http://lion.chadwyck.co.uk/

OED Online. www.oed.com.

'The Isle of Dogs: Introduction', Survey of London: volumes 43 and 44: Poplar, Blackwall and Isle of Dogs (I994), pp. 375-387. URL: http://www.britishhistory.ac.uk/report.aspx?compid=46507. Date accessed: I 5 November 20 I 2.

'The West India Docks: The buildings: warehouses', Survey of London: volumes 43 and 44: Poplar, Blackwall and Isle of Dogs (I994), pp. 284-300. URL: http://www.british-history.ac.uk/report.aspx?compid=46497. Date accessed: I6 November 2012. 